\title{
LABOR EARNINGS AND HOUSEHOLD INCOME MOBILITY IN REUNIFIED GERMANY: A COMPARISON OF THE EASTERN AND WESTERN STATES
}

\author{
By Richard Hauser and Holger Fabig \\ Goethe University Frankfurt
}

\begin{abstract}
Using data from the German Socio-Economic Panel, we compare income mobility of persons from the eastern and western states of Germany between 1990 and 1995. We consider income mobility between consecutive years and between the first and the final year of this time period. We find that gross individual labor income mobility was much higher in the east than in the west during the first years after reunification, but that this difference has become much smaller until 1995. Changing to measures that reflect economic well-being more accurately, we observe that gross equivalent labor income mobility and net equivalent income mobility initially were also much higher in the eastern states than in the western states, but converged over time as well. This convergence has been particularly strong for net equivalent income mobility, suggesting that the social protection system has greatly reduced mobility risks associated with the transformation process in the eastern states of Germany.
\end{abstract}

\section{INTRODUCTION}

Income mobility is a natural consequence of the competitive process in market economies which rewards those who correctly adapt to change and punishes those who do not. ${ }^{1}$ However, in market economies, certain economic risks associated with income loss-unemployment, disability, etc.--are at least partly compensated by a social protection system. Centrally planned socialist economies, on the other hand, by greatly reducing the exposure of employees to economic risks, show a smaller degree of income mobility and less necessity to compensate for unfavorable events, but they do so at the cost of individual freedom and economic growth. ${ }^{2}$

Dramatic political changes in central and eastern Europe at the end of the 1980 s led to changes in their economic systems from centrally planned to more market-driven. The reunification of Germany led to the immediate and complete transfer of West German institutions, including its economic and social protection

Note: This paper is a revised version of a paper given at the Twenty-Fourth General Conference of the International Association for Research in Income and Wealth in Lillehammer, Norway, in 1996. We gratefully acknowledge comments by Tom Juster, Richard Burkhauser, and participants of a session in Lillehammer. We also thank two anonymous referees whose comments helped us to improve an earlier version of this paper. Parts of this paper were financed by the National Institute on Aging, Program Project 1-PO1-AG09743-01, "The Well-Being of the Elderly in a Comparative Context."

'It should be emphasized from the very beginning that we mean by income mobility changes of the relative position of persons across time based on their gross individual labor income, gross equivalent labor income or net equivalent income. We do not look at geographic or occupational mobility.

${ }^{2}$ Of course, income mobility can also arise simply due to good and bad luck. However, the impact of good or bad luck on income should, at least on average, be larger in market economies than in centrally planned economies. 
systems, to the former East Germany, which had been a centrally planned economy.

This extraordinary historical event raises two questions: first, did labor earnings mobility in the eastern states of Germany rise to or above the level of such mobility in the western states of Germany following reunification? Second, did the German social protection system ameliorate some of the mobility risks in labor earnings associated with the transformation to a market economy in the eastern states and yield mobility patterns in household size-adjusted income similar to those observed in the western states?

It is not an easy task to measure income mobility and to make comparisons between geographical units. From a distribution perspective, at least three dimensions of income mobility can be distinguished: first, income mobility defined as changes in the relative position achieved by gross individual labor income, that is, personal pre-tax labor earnings; second, income mobility defined as changes in the relative position with respect to gross equivalent labor income, that is, total pre-tax household size-adjusted labor earnings; and third, income mobility defined as changes in relative position with respect to net equivalent income, that is after-tax and transfer household size-adjusted income from all sources. ${ }^{3}$

Very little is known about these dimensions of income mobility. For highly industrialized market economies, cross-section analyses usually find small changes in the distributions of wages and net equivalent income, suggesting stratified societies (Atkinson, Rainwater and Smeeding, 1995; Hauser and Becker, 1997). In contrast, longitudinal studies based on panel data support the view of fairly mobile societies, at least with respect to net equivalent income. For the U.S., Duncan et al. (1984) found high levels of mobility into and out of poverty in the 1970 s and early 1980s. Jarvis and Jenkins (1996) also found considerable income mobility in the U.K. between 1991 and 1994. Gustafsson (1994) derives the same result for Sweden between 1971 and 1981. Hauser and Berntsen (1992) and Berntsen (1992) showed that there was considerable mobility at all levels of the income distribution in West Germany in the early 1980s, and Habich and Krause (1994) found similar results for the western states of Germany through the end of the decade and into the early 1990s. Studies based on a cohort of Bremen social assistance recipients found high mobility at this lowest level of the social protection system in Germany. Less than 25 percent of social assistance recipients remained on the program for more than five years (Leibfried and Leisering, 1995). On the other hand, Schlueter (1996), who investigated income mobility in the western states of Germany during the 1990s, finds that "a person's income position is strongly persistent" (p. 19). In contrast to this finding, Steiner and Kraus (1996) found a large degree of income mobility in the eastern states of Germany in the early 1990 s. Mueller and Frick (1996) were among the first to compare income mobility in the eastern and western states of Germany. They

\footnotetext{
${ }^{3}$ Average real labor earnings and average real net equivalent income increased far more in the eastern than in the western states of Germany following reunification (Sachverstaendigenrat zur Begutachtung der gesamtwirtschaftlichen Entwicklung, 1995). This paper will focus on the distribution of earnings and income, however, so that changes in the level of the various income concepts are not taken into account. Here, we are only interested in how individuals change their relative positions in the distribution.
} 
found considerable differences in net equivalent income mobility during the period 1990 to 1994. Mathwig and Habich (1996), using gross individual income as their unit of interest, also found considerable differences in mobility between 1990 and $1994 .^{4}$

Comparative studies of income mobility in highly industrialized market economies are rare. Comparisons of income mobility in the U.S. and West Germany in the 1980s by Burkhauser, Holtz-Eakin, and Rhody $(1997,1998)$ produced the surprising result that despite the great differences in labor market regulations, tax systems, and social protection systems, income mobility with respect to labor earnings and net equivalent income was approximately the same in the two countries.

To our knowledge, no panel data studies on income mobility in centrally planned socialist economies exist. Nor are we aware of studies that analyze the changes in income mobility following a change from a centrally planned socialist economy to a market-based economy. Our study is an attempt to fill this gap in the literature. ${ }^{5}$

In Section 2 we describe the data and methods used to analyze mobility. In Section 3 we compare income mobility in the eastern and western states of Germany with respect to gross individual labor income, gross equivalent labor income, and net equivalent income and we analyze the impact of the German social protection system on mobility as measured by these variables. Section 4 concludes.

\section{Data And Methods}

Our empirical results are based on data from the German Socio-Economic Panel (GSOEP). These data were developed at the Universities of Frankfurt and Mannheim in cooperation with the Deutsches Institut fuer Wirtschaftsforschung (DIW), Berlin, and Infratest Sozialforschung, Munich. In 1990 the DIW assumed control of the panel. The panel started with approximately 6,000 households in 1984 in the western states of Germany. These data are representative of the population living in the western states of Germany including foreign "guest workers." About two months before German monetary union was established, the panel was extended to the eastern states, thus covering the last days of the old East German regime. The 1990 wave of the GSOEP contains approximately 2,100 households in the eastern states of Germany. Each component of the GSOEP contains weights permitting a replication of the population in each year for use in cross-sectional analysis. Additionally, the data set contains longitudinal weights that correct at the individual level for persons who have left the panel

\footnotetext{
${ }^{4}$ The authors are well aware of the fact that qualitative terms like "high levels of mobility," "a large degree of income mobility" and "considerable differences" between some mobility values may sound somewhat vague to the reader. However, it is beyond the scope of this introduction to discuss in detail the various mobility measures and the values they take on in these particular studies. Consequently, the reader is referred to these studies in order to obtain the quantitative values on which all these statements are based.

${ }^{5}$ Since these results refer to the special German case, however, generalizations with respect to other post-socialist countries would be premature.
} 
prematurely. Using these weights it is possible to derive representative results by observing individuals over time, as is the case with our mobility analysis. ${ }^{6}$

Our analysis focuses on persons who were either working or registered as unemployed in 1990, and follows their paths through 1995. ${ }^{7}$ To avoid confusion between mobility of persons of working age and those who left the labor force because they reached mandatory retirement age, we additionally restrict our sample to persons who were aged 18 to 54 in $1990 .{ }^{8}$ Our sample consists of 2,920 persons living in the eastern states of Germany and 4,943 persons living in the western states of Germany in 1990. Those who moved from one part of Germany to another between 1990 and 1995 are counted as members of their original location group. In 1995, the West German subsample still contains 3,909 and the East German subsample 2,211 cases. Sample attrition is clearly an issue, but it should be noted that part of this attrition is controlled for by using the longitudinal weights described above and that in the six-year period from 1990 to 1995 it was not dramatically higher in the east than in the west ( 24 percent vs. 21 percent).

We consider three different income concepts: gross individual labor income, gross equivalent labor income, and net equivalent income. We choose multiple measures because we are interested in multiple outcomes. While labor earnings mobility may offer important insights into the functioning of the labor market and its institutions, it is not a good measure of economic well-being. People live in households where they share resources and where additional earners may be present. Hence, an individual's share of household income is a better measure of economic well-being than individual earnings. Assuming equal sharing and some returns to scale for those who live with others, gross equivalent labor income is the appropriate income concept to address these issues.

\footnotetext{
${ }^{6}$ More precisely, weighting was done as follows. For each longitudinal analysis each person belonging to the data set was assigned a separate weight. For example, income mobility between 1990 and 1995 was evaluated using the appropriate longitudinal weights resulting from multiplying the cross-sectional weight of 1990 with the reciprocal value of the probabilities that the person under consideration will stay in the panel in 1991, 1992 and so on. Income mobility between 1992 and 1993 was evaluated using the longitudinal weights resulting from multiplying the cross-sectional weight of 1992 with the reciprocal value of the probability that the person under consideration will stay in the panel in 1993. These probabilities in turn are part of the GSOEP data set and they are calculated by the staff of the Deutsches Institut fuer Wirtschaftsforschung (DIW), Berlin, by using a multiple logit model in which the dependent variable is the conditional probability of staying in the panel and the independent variables are various household characteristics (e.g. age and sex of household head, household type, marital status, changes in household composition, relocation of the whole household, unemployment among household members, living on social assistance, income, wealth and change of interviewer). This procedure accounts explicitly for the non-random nature of sample attrition. For more details, see Pannenberg and Rendtel (1996) and Rendtel (1993). Mean incomes for all income concepts were calculated using the appropriate cross-sectional weights for the respective years.

${ }^{7}$ In this paper we are interested in income mobility during the first years of the transformation of East Germany from a socialist system to a market oriented system under the special circumstances of German reunification, i.e. the period 1990-95. Income mobility in West Germany serves as a path of reference during this transformation period. We did not try, therefore, to exploit information contained in the GSOEP for earlier or later years.

${ }^{8}$ At that time open unemployment did not exist in East Germany while it was about 7.2 percent in West Germany. In 1995 the respective figures were 14.9 and 9.3 percent (see Institut der deutschen Wirtschaft, 1996)
} 
A second reason to look at other outcome measures is to focus on the importance of government policy on economic well-being. The tax, transfer and social protection systems redistribute income among the members of the society. To measure the effects of these systems on market-driven outcomes, we look at income net of taxes but including transfers. Hence, we analyze gross equivalent labor income as a proxy for pre-government equivalent income, and net equivalent income, that is, post-government income. This distinction can then be used to see how in the household context the presence of government affects income mobility. ${ }^{9}$

Comparing incomes in the eastern and western states of Germany might seem difficult, at least for the year 1990, because income data for East Germany was collected in East German marks. However, since the monetary union of July 1990 replaced the East German mark with the West German deutsche mark at a one-to-one rate, the data collected in East German marks can be taken as a good approximation for the 1990 deutsche mark income of East Germans (see Hauser and Wagner, 1996, p. 93).

All income measures are defined monthly. Information on gross individual labor income is obtained directly from the panel. However, we also include information on yearly bonus and other compensation (if paid, and after division by 12). Our measure of gross equivalent labor income is based on this measure of gross individual labor incomes for all household members divided by the equivalence weights of the household based on an OECD developed equivalence scale. ${ }^{10}$ Net household income is taken directly from the panel questionnaire. We add the post-government value of the above-mentioned bonuses to this amount and again divide by the sum of the equivalence weights. ${ }^{11}$

Mean values of these income concepts were computed separately for the eastern and western states of Germany. ${ }^{12}$ Relative income positions for every person in every year were computed by dividing their income by the mean value of the income concept under consideration. People were then grouped into brackets according to their position relative to the mean for each income concept. The first bracket contains the unemployed, the second bracket individuals whose relative

\footnotetext{
${ }^{9}$ We do not include the rental value of owner occupied houses because data on this income component is not fully available. Other income from capital is included in net equivalent income, but not in gross individual and gross equivalent labor income. Since income from capital cannot be separated, our measure will slightly overstate the dampening effects of taxes and transfers.

${ }^{10}$ The OECD scale assigns a weight of 1 to the head of household, weights of 0.7 to other members aged 15 and older, and 0.5 to household members below 15. For an international comparison of equivalence scales and the consequences of using different scales, see Buhmann et al. (1988) and Burkhauser et al. (1996). A new study by Hauser and Faik (1996) shows that the equivalence scale implied in German regulations for social protection is similar to the OECD scale used.

${ }^{11}$ Post-government income from bonuses etc. is determined by deducting 35 percent of the gross amount for taxes and social security contributions.

${ }^{12}$ The following four groups of persons were deleted from the sample because of implausibility: First, people working full or part time who reported monthly incomes below 100 DM (regardless of the income concept under consideration). Second, people being registered as unemployed who reported a non-zero gross individual labor income. Third, people being registered as unemployed who reported a gross equivalent labor income below $100 \mathrm{DM}$. (This was done for the following reason: If nobody else in the household is employed, gross equivalent labor income is zero as well. If somebody else in the household is employed, gross equivalent labor income has to be higher than 100 DM.) Fourth, people being registered as unemployed who reported a net equivalent income below $100 \mathrm{DM}$. All these procedures taken together exclude between 1.2 and 2.4 percent of cases.
} 
incomes are below 0.5 of mean income, the third bracket those with incomes between 0.5 and below 0.75 , the fourth bracket those with incomes between 0.75 and below 1.0, the fifth bracket those with incomes between 1.0 and below 1.25 , the sixth bracket those with incomes between 1.25 and below 1.5 and the seventh bracket those with incomes of 1.5 and more of mean income. The first income bracket is only defined for the analysis of gross individual labor income mobility. It is ignored when equivalent income concepts are analyzed, so that in this case the second bracket becomes the first and so on. Individuals belonging to households that are struck by unemployment are assigned the income bracket they belong to according to their relative income.

This choice of income brackets allows us to study income distribution dynamics. In contrast to quantile income brackets where every income class contains, by definition, the same percentage of the population, the percentage of people in certain relative income brackets can change over time. Thus the marginal distributions in each transition matrix gives us an idea of how the income distribution changes. The particular choice of thresholds has been motivated by the fact that having less than 0.5 of mean income is a frequently used poverty definition, so that our definition of income brackets allows the study of poverty dynamics (at least when considering net equivalent income) ${ }^{13}$ From this threshold on, we continue in 0.25 -steps until we reach 1.5 which is the "richness threshold" symmetric to the poverty threshold. Also note that using relative income brackets leads to income brackets of equal size in terms of income around the mean of the income distribution. This is important when comparing two economies with different degrees of inequality like East and West Germany. Using quantile income brackets in this case would lead to much smaller income brackets around the mean in the economy with the more equal income distribution. Then, a given increase in income could lead to a movement into a higher income bracket in the more equal economy whereas no change would be observed in the other.

This grouping is not fully satisfactory since it ignores movements within the brackets and especially all income mobility above 1.5 times mean income. It has the further weakness that people close to the border of a particular income bracket are moved from one bracket to another by small changes in income. However, these relative income brackets allow us to operationalize the complex phenomenon of social mobility. The resulting mobility matrices offer a convenient way to track movements of people among income brackets in a single table. ${ }^{14}$ Mobility indices can then aggregate the information contained in these transition

\footnotetext{
${ }^{13}$ See, for example, Hauser and Berntsen (1992) and Jarvis and Jenkins (1996).

${ }^{14} \mathrm{It}$ is clear that the number of people whose income dynamics are analyzed in a mobility matrix is determined by the number of the people still in the panel at the end of the observation period. E.g. when analyzing income mobility between 1990 and 1995 in West Germany, only 3,909 out of the original 4,943 (unweighted) cases can be analyzed. When analyzing income mobility between 1992 and 1993, say, we have not restricted our analysis to the 3,909 cases that stayed in the panel during the whole observation period. Instead, we considered all cases out of the 4,943 cases in 1990 that were still in the panel in 1993 which are more than 3,909. As was pointed out before, weighting was done by using the appropriate longitudinal weights which are not the same for the transitions 1990-95 and 1992-93. The cell entries in terms of (unweighted) persons can readily be computed by multiplying the number of persons still in the panel at the end of the observation period with the appropriate marginal probability in the rightmost column of the mobility matrix and with the transition probabilities in the cell of the matrix one is interested in.
} 
matrices into a single number. In this paper, we focus on the Bartholomew index. This index is based on the share of persons that move to another income bracket between the years of reference. A value of zero means no mobility. The higher the index, the greater is the mobility. The formula for calculating the Bartholomew index is

$$
B I=\sum_{i=1}^{n} \sum_{j=1}^{n} p_{i} \cdot p_{i j}|i-j|, \quad i, j=1, \ldots, n,
$$

where $p_{i j}$ refers to the elements of the mobility matrix. It is the fraction of those people who were in income bracket $i$ in the first year and were in bracket $j$ in the last year. $p_{i}$. is the fraction of the whole sample that was in income bracket $i$ in the first year and $n$ represents the number of income brackets. ${ }^{15}$ This index assigns weights based on how far a person moves from his or her initial income bracket. The Bartholomew index is therefore sensitive to the number of income brackets considered. ${ }^{16}$

In order to make up for some of the weaknesses of the Bartholomew index, we additionally compute the Pearson correlation coefficient between relative income positions in different years and for different income concepts. This measure needs no classification of incomes into income brackets and is bounded from above by one. This normalization allows a straightforward comparison of various correlation coefficients. The higher the coefficient, the stronger the correlation between the two incomes and the lower income mobility.

Although the Gini coefficient is not a measure of income mobility, we also report Gini coefficient values for the various income concepts in 1990 and 1995. Since income mobility is a necessary but not sufficient condition for changes in the aggregate income distribution, the purpose of reporting the changes of the Gini coefficient at the end of each subsection is to see by how much income mobility has changed the overall income distribution.

\section{Mobility Across Gross Individual Labor, Gross Equivalent Labor and Net Equivalent Income Groups in Germany}

This section compares income mobility in the eastern and western states of Germany with respect to three different income concepts. We consider both

\footnotetext{
${ }^{15}$ Note that $\sum_{j=1}^{n} p_{i j}=1$ and $\sum_{i=1}^{n} p_{i}=1 . p_{i j}$ can be interpreted as a conditional probability because it is the probability that a person moves to bracket $j$ given that he or she has been in bracket $i$ in the initial period. The above formulation of the Bartholomew index is a slight modification of the index derived by Bartholomew (1973, p. 24). $n=7$ when gross individual labor income mobility is analyzed and $n=6$ when we consider equivalent income concepts.

${ }^{16}$ Other mobility indices have been suggested. A particularly common index was proposed by Shorrocks (1978a), focusing on the main diagonal of the transition matrix: $S I=\left(n-\sum_{i=1}^{n} p_{i i}\right) / n-1$. Although we also calculated $S I$ results they are not reported here because they do not substantially differ from those arrived at with the Bartholomew index. $S I$ should not be confused with the measure termed the "Shorrocks index" by Jarvis and Jenkins (1996) which was proposed by Shorrocks (1978b). The latter is equal to the inequality measure for a longer-period income obtained by aggregating period income over $m$ periods divided by the weighted average of the $m$ sub-period inequality measures of the respective period's income. "Under this definition, mobility is regarded as the degree to which equalization occurs as the observation period is extended" (Shorrocks 1978b, p. 386).
} 
income mobility between the first and the final year of our observation period (i.e. for the transition 1990-95) and also between two consecutive years (i.e. for the transitions 1990-91, 1991-92, 1992-93, 1993-94, 1994-95).

\section{Gross Individual Labor Income Mobility}

In centrally planned economies, wages tend to be more equally distributed than in market economies. Thus, many economists expected an increase in wage inequality in the eastern states of Germany after reunification. In fact, Steiner and Puhani (1996) find that an increasing spread of hourly wages did occur, although at a slower pace than expected. In contrast, the spread of hourly wages remained fairly constant in the western states.

The increasing wage spread in the eastern states of Germany probably contributed to greater gross individual labor income mobility, but more important to mobility was the enormous increase in unemployment following reunification. In 1990, open unemployment in the eastern states did not exist. By 1995 it was measured at 16.9 percent. In the western states the unemployment rate was 4.3 percent in 1990 . It rose to 7.5 percent in $1995 .{ }^{17}$ Since we are looking at gross individual labor income of all persons in the labor force, unemployment implies a complete loss of income from labor and, therefore, downward mobility. The larger increase in unemployment in the eastern states means that this downward mobility should be more pronounced in the east than in the west. Additionally, the enormous industrial changes in the eastern states increased the risks of being either promoted or downgraded and thus increased overall mobility to a level higher than that of the rather stable economy of the western states. The mobility matrices in Table 1 confirm these presumptions.

We find much higher mobility across relative gross individual labor income brackets in the eastern than in the western states between 1990 and 1995: the percentages of stayers in the east are roughly one-half of those in the west, and all these East German percentages differ significantly from the West German values at the 1 percent level. ${ }^{18} \mathrm{~A}$ simultaneous test of all diagonal elements also

\footnotetext{
${ }^{17}$ These unemployment rates are based on the GSOEP data at the time of the interviews. We have reported official unemployment rates for the respective months above. Differences between the official rates and the GSOEP figures can be explained by the exclusion of some age cohorts of the labor force from our analysis, by sampling periods of the GSOEP of more than one month and by sampling errors.

${ }^{18}$ The first income bracket labeled "unemployed" is empty in 1990 for the eastern states since there was no open unemployment in East Germany. Persons who left the labor force because of early retirement are excluded from this analysis. According to the extensive study of Mathwig and Habich (1996), 8.9 percent of those East Germans that were employed in 1990 and were at working age throughout the period 1990-94 took part in some early retirement scheme in 1994 whereas only 0.9 percent of West Germans did so. However, the early retirees were not hit harder by the transformation process than the unemployed because the transfer payments of the early retirement schemes were quite similar to those of the unemployment insurance, as Hauser et al. (1996, pp. 57-60) point out. Consequently, the German social security system has also done an effective job in helping the early retired. Including the early retirees would lead to a larger fraction of people in East Germany whose gross individual labor income is characterized by a large downward mobility whereas their net equivalent income is characterized by a much smaller downward mobility. Thus, the mobility dampening effect of the social security system would seem even stronger.
} 
TABLE 1

Gross Individual Labor Income Mobility in the Eastern and Western States of Germany Between 1990 and 1995

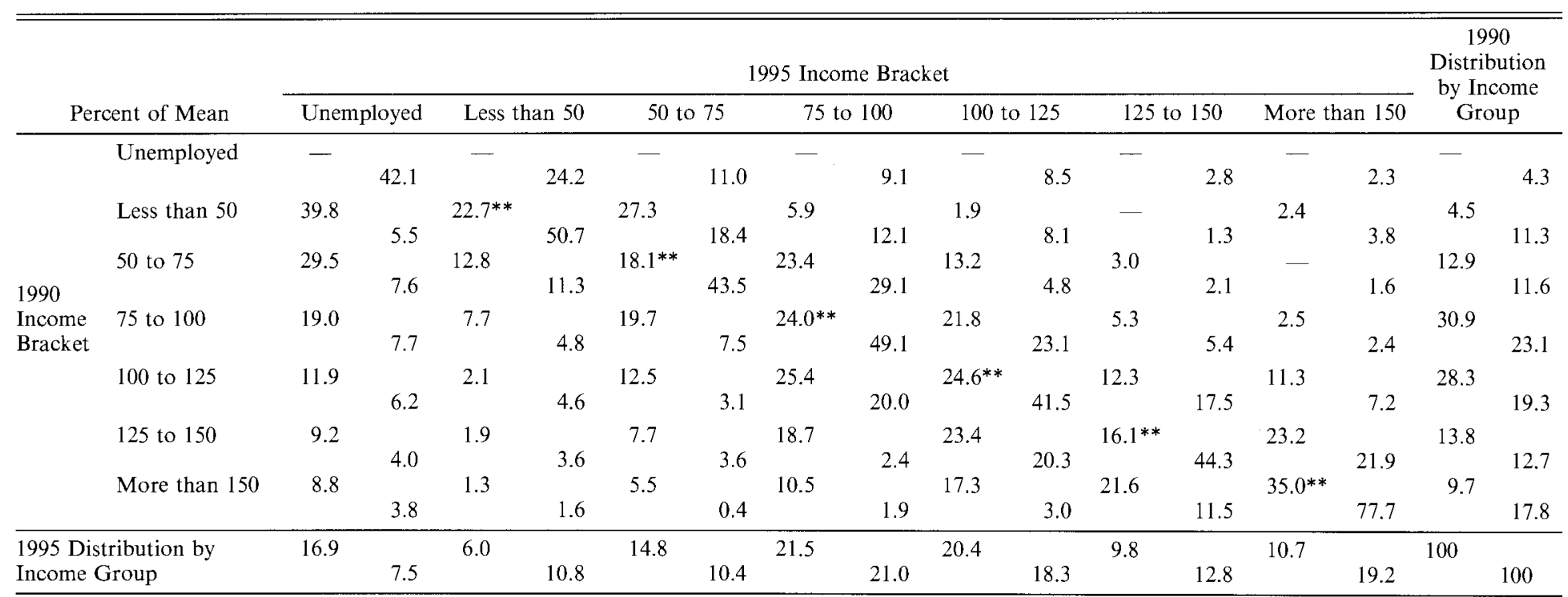

Source: Authors' calculations.

Data base: GSOEP 1990-95.

Note: Percent of population in a given row income bracket in 1990 that moved to a given column income bracket in 1995 . The upper left corner percentages in the cells refer to the eastern states of Germany and the lower right corner percentages refer to the western states of Germany.

**Indicates that the eastern and the western rates are significantly different at the 1 percent level. 
shows a highly significant difference between the eastern and the western states. ${ }^{19}$ This finding of much higher gross individual labor income mobility in the east is further confirmed in Table 2, which shows the Pearson correlation coefficients of the individual relative positions between the two years. The value is 0.42 for the eastern states and 0.68 in the western states (column 1, row 4). Figure 1 shows the Bartholomew index value which aggregates the information contained in Table 1. Again, gross individual labor income mobility is higher in the eastern than in the western states.

The higher mobility in the east should taper off as the transition process progresses and the structural changes diminish to a level typical of market economies. It is, therefore, interesting to look at the values of the Bartholomew index calculated from the mobility matrices for the transitions for two consecutive years. ${ }^{20}$ These values are represented in Figure 2 . It shows that yearly gross individual labor income mobility peaked in the eastern states in 1991-92 and has fallen in subsequent years. By 1994-95 it approached the mobility level in the western states. As one can derive from Table A1 in the Appendix, the difference in the Bartholomew index between the eastern and the western states was 0.37 for the transition 1990-91, or 58.4 percent of the West German index value for 1990-91. For the transition 1994-95, this difference has fallen to 0.19 or 30.3 percent of the West German index value for 1990-91. Thus, for the transition 1994-95 the difference in the index values as a percentage of the 1990-91 index value was only 50 percent of the difference for the transition 1990-91. ${ }^{21}$

Income mobility is a necessary, but not a sufficient condition for changes in the aggregate income distribution. It is therefore interesting to investigate whether the mobility of gross individual labor income discussed above led to changes in the overall distribution of income from wages. Table 3 presents Gini coefficients for both the eastern and western states. They show that inequality rose by 29.9 percent in the eastern states between 1990 and 1995, but by only 2.6 percent in western states. Inequality was higher in the western states than in the eastern states both in 1990 and in 1995, although by 1995 the gap had been reduced to approximately 50 percent of the initial difference.

\footnotetext{
${ }^{19}$ The significance test for pairs of diagonal cell entries was performed as follows (see Schlitgen, 1996, p. 350). Let $\hat{p}_{1}$ denote the East German and $\hat{p}_{2}$ the West German percentage of stayers in income bracket $k, k=1, \ldots, K$, where $K$ is the number of income brackets. Let $n$ denote the East German and $m$ the West German sample size. Finally, define $\hat{p}=1 /(n+m)\left(n \hat{p}_{1}+m \hat{p}_{2}\right)$. Then, $T_{k}=$ $\left(\hat{p}_{1}-\hat{p}_{2}\right) / \sqrt{\hat{p}(1-\hat{p})(1 / n+1 / m)} \sim N(0,1)$, approximately, if $n$ and $m$ are large (which is the case in the present study). For the simultaneous test of all diagonal elements, we use the fact that $\sum_{k=1}^{K} T_{k}(1 / \sqrt{K}) \sim N(0,1)$, approximately, if $n$ and $m$ are large. Thus, the significance level of the difference between the single percentages as well as between all diagonal elements taken together can be obtained from the ordinary table for the standard normal distribution. Following the usual terminology, we call a difference that is significant at the 5 percent level "significant" and a difference that is significant at the 1 percent level "highly significant."

${ }^{20}$ We calculated the matrices for the transitions 1990-91, 1991-92, 1992-93, 1993-94 and 1994 95 in a similar manner to the one reported in Table 1 which displays the transition 1990-95. For the sake of brevity, these matrices are not included in this paper, but are available from the authors upon request.

${ }^{21}$ The changes of the Bartholomew index are compared to its initial level in West Germany because we consider this level as a "normal" level of income mobility in a stable market economy. Some previous studies (e.g. Headey and Krause, 1995; Trede, 1997) show that this level of mobility did not change much from 1984 to 1990
} 
TABLE 2

Pearson Correlation Coefficients of the Relative Income Positions of Persons living Originally in the Eastern and Western States of Germany Between 1990 and 1995

\begin{tabular}{|c|c|c|c|c|c|c|c|}
\hline & \multirow[b]{2}{*}{ Income concept } & \multicolumn{3}{|c|}{1990} & \multicolumn{3}{|c|}{1995} \\
\hline & & $\begin{array}{c}\text { Gross } \\
\text { Individual } \\
\text { Labor Income }\end{array}$ & $\begin{array}{c}\text { Gross } \\
\text { Equivalent } \\
\text { Labor Income }\end{array}$ & $\begin{array}{c}\text { Net } \\
\text { Equivalent } \\
\text { Income }\end{array}$ & $\begin{array}{c}\text { Gross } \\
\text { Individual } \\
\text { Labor Income }\end{array}$ & $\begin{array}{c}\text { Gross } \\
\text { Equivalent } \\
\text { Labor Income }\end{array}$ & $\begin{array}{c}\text { Net } \\
\text { Equivalent } \\
\text { Income }\end{array}$ \\
\hline \multirow[b]{2}{*}{1990} & $\begin{array}{l}\text { Gross Individual } \\
\text { Labor Income }\end{array}$ & 1.00 & & & & & \\
\hline & $\begin{array}{l}\text { Gross Equivalent } \\
\text { Labor Income }\end{array}$ & 0.48 & 1.00 & & & & \\
\hline \multirow[b]{2}{*}{1995} & $\begin{array}{l}\text { Gross Individual } \\
\text { Labor Income }\end{array}$ & 0.42 & 0.18 & 0.17 & 1.00 & & \\
\hline & $\begin{array}{l}\text { Gross Equivalent } \\
\text { Labor Income }\end{array}$ & 0.27 & 0.40 & 0.36 & 0.61 & 1.00 & \\
\hline
\end{tabular}

Source: Authors' calculations.

Data base: GSOEP 1990-95.

Note: The upper left values in the cells refer to the eastern states of Germany, the lower right values refer to the western states of Germany. 


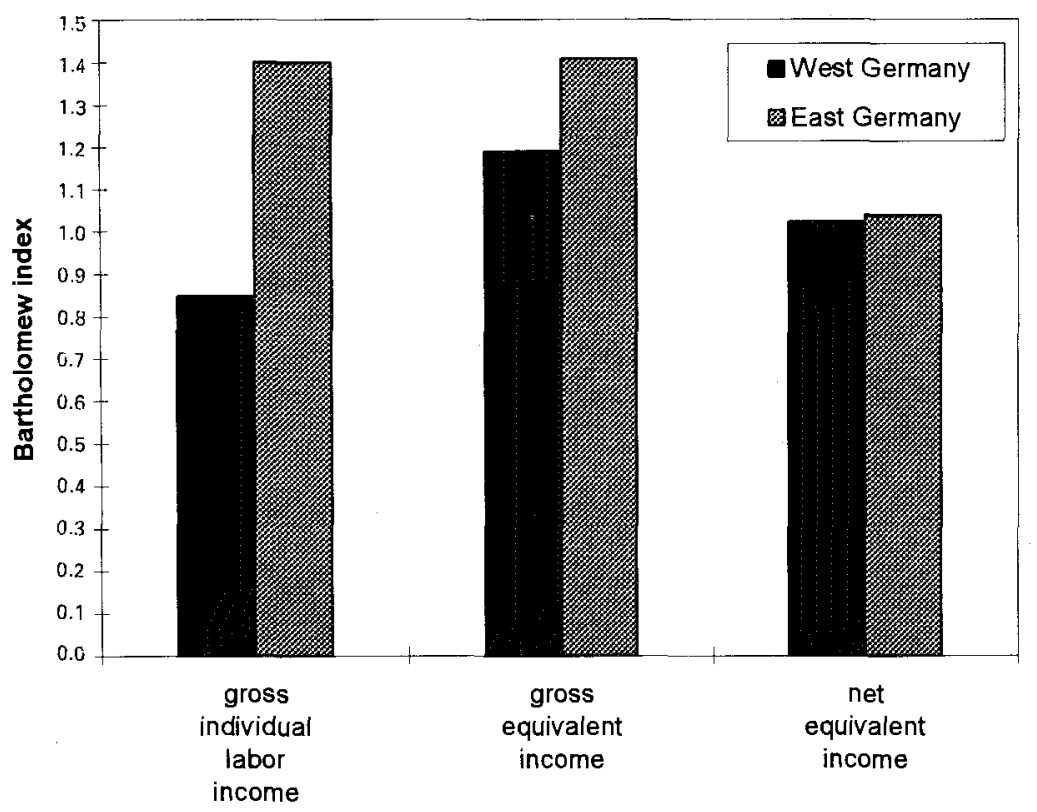

Source: Authors' Calculations as Shown in Table A1 in the Appendix Data base: GSOEP $1990-95$

Figure 1. Income Mobility in Regions of Germany Between 1990 and 1995

\section{Gross Equivalent Labor Income Mobility}

Historically, the family has played an important role in providing social and income security, especially for the old, sick and handicapped, but also for the unemployed. Against this background this subsection introduces the household context to the analysis of income mobility by analyzing gross equivalent labor income mobility.

Changing the viewpoint from gross individual labor income mobility to gross equivalent labor income mobility brings into play what we would like to call the household effect, i.e. the change in one's relative income position associated with household size, the age of household members, and the number of earners in the household. This household effect shows up in a rearrangement of the relative positions when one changes the viewpoint from gross individual labor income to gross equivalent labor income within a given period. However, the household context also influences income mobility over time in addition to the influence of individual wage changes and the possibility of individual unemployment. First, changes in the number and the age of the household members result in changes of the sum of the individual equivalent weights. ${ }^{22}$ These changes result in substantial

${ }^{22}$ Note that according to the old OECD equivalence scale, the weight of household members other than the head changes from 0.5 to 0.7 as soon as they become older than fourteen. If a couple splits into two single households, the sum of the weights changes from 1.7 to 2.0 while it is reduced from 2.0 to 1.7 if two singles living in one person households form a new two-person household. 


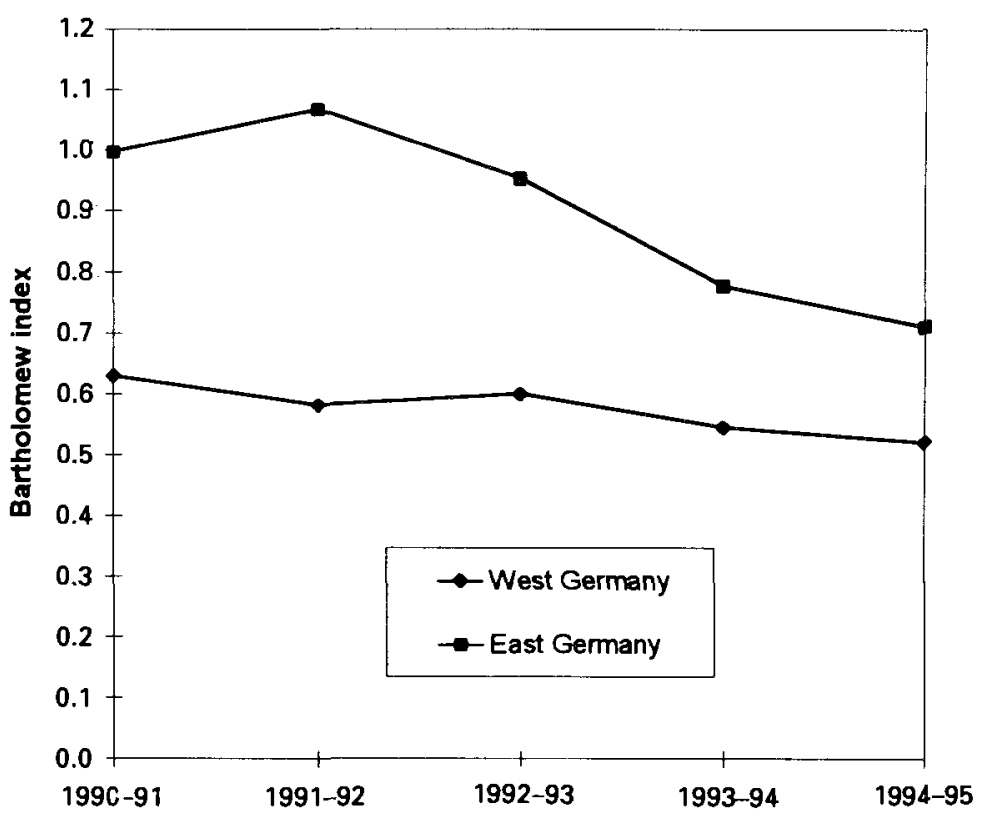

Source: Authors' Calculations as Shown in Table Al in the Appendix Data base: GSOEP 1990-95

Figure 2. Gross Individual Labor Income Mobility in Regions of Germany

TABLE 3

Gini Coefficients for the Eastern and Western States of GERMANY IN 1990 AND 1995

\begin{tabular}{lcccccc}
\hline \hline & \multicolumn{2}{c}{ Eastern States } & & \multicolumn{2}{c}{ Western States } \\
\cline { 2 - 3 } \cline { 6 - 7 } \multicolumn{1}{c}{ Income Measure } & 1990 & 1995 & & 1990 & 1995 \\
\hline Gross Individual Labor Income & 0.1939 & 0.2519 & & 0.3062 & 0.3141 \\
Gross Equivalent Labor Income & 0.2204 & 0.2876 & & 0.3133 & 0.3287 \\
Net Equivalent Income & 0.1710 & 0.2263 & & 0.2619 & 0.2857 \\
\hline
\end{tabular}

Source: Authors' calculations.

Data base: GSOEP 1990-95.

changes of the relative income positions, and thus clearly lead to higher mobility. ${ }^{23}$ Additionally, changes in the number of earners may increase equivalent income mobility. However, mobility can also be reduced when individual wages are only part of a larger pool of financial resources, and mobility is dampened by their constancy or even compensated for by opposite movements of other

${ }^{2.3}$ Although we now include the influence of all persons living in a household, it should be kept in mind that only those persons who worked full- or part-time or who were unemployed and who were aged 18 through 54 in 1990 are included in the analysis. Other persons influence mobility only indirectly via the equivalent income weight. 
resources. On the other hand, income pooling within the family does not necessarily lead to a reduction of income mobility. Changes of income can also go in the same direction for all household members, i.e. the household is also pooling income risk. ${ }^{24}$

The influence of these various factors can be seen in Table 2. The Pearson correlation coefficient between the relative positions according to gross individual and gross equivalent labor income in 1990 is 0.48 in the east and 0.73 in the west (column 1, row 2). A partial explanation for the stronger household effect in the east can be found in the labor market experience of women. In 1990 the labor force participation rate of women in the eastern states was much higher than in the western states while rates for men were about the same. ${ }^{25}$ This means that there were more multiple labor earnings families in the east than in the west. ${ }^{26}$

Table 4 presents the gross equivalent labor income mobility matrices for the eastern and western states. Again, the main diagonal shows a greater share of stayers in the west than in the east. Notably, the difference is no longer double, and while four out of six diagonal cell entries still differ significantly at the 1 percent level, two do not differ significantly at all. However, a simultaneous test of all diagonal elements still yields a highly significant difference between East Germany and West Germany. In sum, the values are now much closer, especially in the two lowest brackets that contain most of the unemployed, directly or indirectly, via the household context.

The Pearson correlation coefficients between one's position in the gross equivalent labor income distribution in 1990 and in 1995 is 0.40 in the east and 0.52 in the west (see column 2, row 5, Table 2). These coefficients are both lower than those we found for gross individual labor income. Figure 1 shows that the two values of the respective Bartholomew index are also closer than those for gross individual labor income. ${ }^{27}$ The Bartholomew indices for consecutive years are depicted in Figure 3. Mobility was highest in 1990-91, but the mobility in the eastern states rapidly approached that in the western states. Although mobility differences between the eastern and western states are smaller when gross equivalent labor income is considered instead of gross individual labor income the same pattern of a rapid reduction of mobility over consecutive years emerges. As can be derived from Table A1 in the Appendix, the difference in the Bartholomew

\footnotetext{
${ }^{24} \mathrm{We}$ owe this last point to an anonymous referee.

${ }^{25}$ The labor force participation rate of women aged between 15 and 65 was 77.2 percent in the eastern states of Germany in 1991 (figures for 1990 not available) and 58.5 percent in the western states of Germany in 1990 . For men the respective rates are 86.0 and 82.7 percent (see Institut der deutschen Wirtschaft, 1996).

${ }^{26}$ Household size itself did not differ substantially. The average household size in the eastern states of Germany was 2.38 in 1991 (figures for 1990 are not available). The respective value for the household size in the western states of Germany was 2.25 in 1990 (see Institut der deutschen Wirtschaft, 1996).

${ }^{27}$ Note that the Bartholomew index values displayed in Figure 1 for gross individual labor income and for gross equivalent labor income are not directly comparable. The Bartholomew index is sensitive to the number of income brackets, and the computation of its values is based on seven income brackets in the first case, but on six income brackets in the second case. This incomparability, however, is not a major problem in the present context since we are interested in comparing the difference between East and West in the mobility values for each income concept so that the bracket effect "cancels out." Moreover, since the number of income brackets is the same for gross and net equivalent income, this problem does not arise when comparing these two income concepts further below.
} 
TABLE 4

Gross Equivalent Labor Income Mobility in the Eastern and Western States of Germany Between 1990 and 1995

\begin{tabular}{|c|c|c|c|c|c|c|c|c|c|c|c|c|c|c|c|}
\hline & & & & & & & $5 \mathrm{Inc}$ & ne $\mathrm{Brac}$ & & & & & & \multirow{2}{*}{\multicolumn{2}{|c|}{$\begin{array}{c}1990 \\
\text { Distribution } \\
\text { by Income } \\
\text { Group }\end{array}$}} \\
\hline \multicolumn{2}{|c|}{ Percent of Mean } & Less $\mathrm{t}$ & an 50 & \multicolumn{2}{|c|}{50 to 75} & \multicolumn{2}{|c|}{75 to 100} & \multicolumn{2}{|c|}{100 to 125} & \multicolumn{2}{|c|}{125 to 150} & \multicolumn{2}{|c|}{ More than 150} & & \\
\hline \multirow{11}{*}{$\begin{array}{l}1990 \\
\text { Income } \\
\text { Bracket }\end{array}$} & Less than 50 & 43.4 & & 25.9 & & 12.1 & & 9.4 & & 7.5 & & 1.8 & & 6.9 & \\
\hline & & & 45.8 & & 19.7 & & 8.9 & & 10.7 & & 5.1 & & 9.8 & & 12.0 \\
\hline & 50 to 75 & 28.8 & & $22.8^{* *}$ & & 20.0 & & 15.5 & & 8.9 & & 4.0 & & 13.7 & \\
\hline & & & 21.1 & & 33.3 & & 24.6 & & 12.5 & & 3.9 & & 4.6 & & 16.7 \\
\hline & 75 to 100 & 20.3 & & 18.5 & & $21.1^{* *}$ & & 24.3 & & 6.0 & & 9.9 & & 22.5 & \\
\hline & & & 12.0 & & 18.9 & & 30.5 & & 16.6 & & 12.1 & & 9.8 & & 17.3 \\
\hline & 100 to 125 & 18.2 & 10.7 & 16.5 & 9.2 & 20.1 & 16.7 & $14.1 * *$ & 30.5 & 18.3 & 16.8 & 12.8 & 16.1 & 23.1 & 15.4 \\
\hline & 125 to 150 & 12.6 & & 9.1 & & 15.2 & & 20.8 & & 19.6 & & 22.8 & & 17.6 & \\
\hline & & & 11.1 & & 11.8 & & 9.7 & & 15.6 & & 24.1 & & 27.7 & & 14.1 \\
\hline & More than 150 & 9.5 & & 5.7 & & 18.6 & & 10.5 & & 13.9 & & $41.8^{* *}$ & & 16.2 & \\
\hline & & & 5.5 & & 8.1 & & 9.0 & & 9.5 & & 8.1 & & 59.7 & & 24.5 \\
\hline \multirow{2}{*}{\multicolumn{2}{|c|}{$\begin{array}{l}1995 \text { Distribution by } \\
\text { Income Group }\end{array}$}} & 19.5 & & 15.4 & & 18.7 & & 16.8 & & 13.0 & & 16.6 & & 100 & \\
\hline & & & 15.7 & & 16.3 & & 16.6 & & 15.5 & & 11.3 & & 24.7 & & 100 \\
\hline
\end{tabular}

Source: Authors' calculations.

Data base: GSOEP 1990-95.

Note: Percent of population in a given row income bracket in 1990 that moved to a given column income bracket in 1995. The upper left corner percentages in the cells refer to the eastern states of Germany and the lower right corner percentages refer to the western states of Germany.

**Indicates that the eastern and the western rates are significantly different at the 1 percent level. 
index between the eastern and the western states was 0.31 for the transition 1990 91, or 41.5 percent of the West German index value for 1990-91. For the transition 1994-95, this difference has fallen to 0.08 or 11.1 percent of the West German index value for 1990-91. Relative to the level of income mobility in West Germany in 1990-91, the mobility difference at the end of the observation period is only one fourth of its initial value.

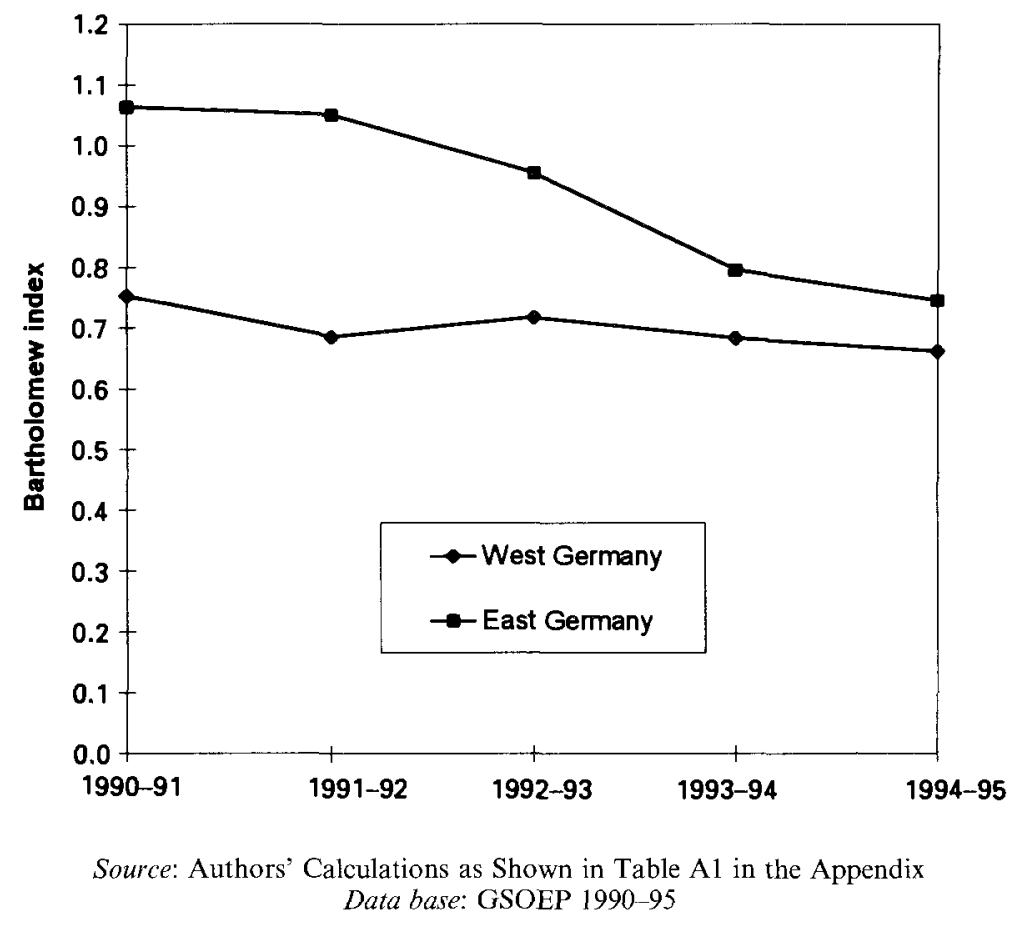

Figure 3. Gross Equivalent Labor Income Mobility in Regions of Germany

Again, it is interesting to see how aggregate inequality developed during the years considered (see Table 3). First, all Gini coefficients for gross equivalent labor income are higher than the Gini coefficients for gross individual labor income. One possible explanation is that the household context leads to many new sources of differentiation for the individual's relative income position. Second, inequality rose in both parts of the country between 1990 and 1995, but to a much larger extent in the eastern states ( 30.5 percent) than in the western states (4.9 percent). Third, inequality was higher in the western states in both 1990 and 1995, although the gap was substantially smaller in 1995.

\section{Net Equivalent Income Mobility}

Our net equivalent income measure allows us to gauge to what extent the tax, transfer and social protection systems in the eastern and western states of 
Germany reduce mobility by comparing net equivalent income mobility with gross equivalent labor income mobility found in the previous subsection.

The main aim of the German social protection system is to ameliorate income losses due to acknowledged social risks. Since the replacement rates vary from 53 percent to almost 100 percent and since most transfer payments are indexed to net wages, relative positions of those who experience a loss of income from wages are not fully protected but the decrease is limited. Furthermore, social assistance guarantees a socio-cultural subsistence level to all regardless of the cause of their income loss. Progressive personal income taxes also aim to reduce upward and downward movements in post tax income. ${ }^{28}$ Thus, we expect gross equivalent labor income mobility to exceed net equivalent income mobility. ${ }^{29}$

Table 5 contains mobility matrices by net equivalent income categories. In contrast to our other two measures of mobility, the percentages of stayers on the main diagonal are very similar in the two regions of Germany and not a single East German percentage differs significantly from the corresponding West German value anymore. A simultaneous test of all diagonal elements shows a significant, but not a highly significant difference between the eastern and the western states. The Pearson correlation coefficients for net equivalent income in 1990 and 1995 in Table 2 are 0.42 (east) and 0.51 (west). This is a smaller difference than that observed for the other two income measures, and, therefore, confirms the narrowing. Figure 1 shows almost no difference between the Bartholomew index values in the two regions. Moreover, both indices are lower than those for gross equivalent labor income, thus revealing the dampening effect of the tax and transfer systems on mobility.

This dampening effect can be seen even more clearly when one considers what we would like to call the Truncated Bartholomew index. This index is derived by applying the formula for the Bartholomew index only to downward movements, i.e. to elements below the main diagonal of the transition matrix while the elements above the main diagonal are ignored as if there were no entries in these cells. Thus, only downward mobility is considered. Using values of changes in absolute terms, the higher this index, the more downward mobility there is. Comparing gross equivalent labor income mobility to net equivalent income mobility for the transition 1990-95, downward mobility was reduced from 0.6541 to 0.5584 in the western states and from 0.9098 to 0.6640 in the eastern states. Thus, the mobility-reducing effect of government intervention was far stronger in the east than in the west. ${ }^{30}$

Again it is worth looking at the underlying dynamics of the five-year transitions. As Figure 4 shows, the reduction of gross equivalent labor income

\footnotetext{
${ }^{28}$ For an overview of the institutional arrangements in Germany, see Hauser and Becker (1997). For a detailed discussion of the labor market regulations and the social security system, see Lampert (1994). A description of the transfer of West German institutions to the eastern states can be found in Bundesministerium fuer Arbeit und Sozialordnung (1995).

${ }^{29}$ However, this approach exaggerates the effects of transfers and taxes because it does not account for individual adjustments in the case of the absence of government activity.

${ }^{30} \mathrm{It}$ is worth noting that the annual net transfers from the western to eastern states amounted to between 5 and 7 percent of the western states' GDP in each of the first five years of the transformation process (Sachverstaendigenrat zur Begutachtung der gesamtwirtschaftlichen Entwicklung, 1995).
} 
TABLE 5

Net Equivalent Income Mobility in the Eastern and Western States of Germany Between 1990 and 1995

\begin{tabular}{|c|c|c|c|c|c|c|c|c|c|c|c|c|c|c|c|}
\hline & & & & & & & 5 Ince & $\mathrm{e} \mathrm{Brac}$ & & & & & & \multirow{2}{*}{\multicolumn{2}{|c|}{$\begin{array}{c}1990 \\
\text { Distribution } \\
\text { by Income } \\
\text { Group }\end{array}$}} \\
\hline \multicolumn{2}{|c|}{ Percent of Mean } & \multicolumn{2}{|c|}{ Less than 50} & \multicolumn{2}{|c|}{50 to 75} & \multicolumn{2}{|c|}{75 to 100} & \multicolumn{2}{|c|}{100 to 125} & \multicolumn{2}{|c|}{125 to 150} & \multicolumn{2}{|c|}{ More than 150} & & \\
\hline \multirow{10}{*}{$\begin{array}{l}1990 \\
\text { Income } \\
\text { Bracket }\end{array}$} & Less than 50 & 37.7 & & 50.1 & & 6.4 & & 5.8 & & - & & - & & 1.5 & \\
\hline & & & 40.5 & & 27.0 & & 13.3 & & 6.3 & & 6.4 & & 6.4 & & 6.6 \\
\hline & 50 to 75 & 13.2 & 13.8 & 36.9 & 41.5 & 27.8 & 23.9 & 13.3 & 8.6 & 2.9 & 4.4 & 5.9 & 7.8 & 11.1 & 18.3 \\
\hline & 75 to 100 & 8.0 & 70 & 23.7 & 02 & 34.7 & 267 & 20.6 & 100 & 7.8 & & 5.1 & & 28.5 & \\
\hline & 100 to 125 & 1.7 & & 17.9 & & 30.5 & & 28.1 & & 15.6 & & 6.2 & & 28.1 & \\
\hline & & & 3.2 & & 14.2 & & 26.8 & & 30.4 & & 15.0 & & 10.5 & & 21.1 \\
\hline & 125 to 150 & 3.6 & & 10.7 & & 17.0 & & 20.2 & & 28.6 & & 19.9 & & 20.2 & \\
\hline & & & 2.7 & & 12.0 & & 11.8 & & 20.3 & & 29.0 & & 24.2 & & 12.9 \\
\hline & More than 150 & 2.5 & & 6.3 & & 7.0 & & 24.8 & & 16.4 & & 43.1 & & 10.6 & \\
\hline & & & 1.1 & & 4.4 & & 11.4 & & 13.5 & & 19.9 & & 49.7 & & 18.9 \\
\hline \multirow{2}{*}{\multicolumn{2}{|c|}{$\begin{array}{l}1995 \text { Distribution by } \\
\text { Income Group }\end{array}$}} & 5.8 & & 19.4 & & 25.8 & & 22.1 & & 14.5 & & 12.5 & & 100 & \\
\hline & & & 8.0 & & 19.8 & & 22.7 & & 18.0 & & 13.7 & & 17.7 & & 100 \\
\hline
\end{tabular}

Source: Authors' calculations.

Data base: GSOEP 1990-95.

Note: Percent of population in a given row income bracket in 1990 that moved to a given column income bracket in 1995. The upper left corner percentages in the cells refer to the eastern states of Germany and the lower right corner percentages refer to the western states of Germany.

**Indicates that the eastern and the western rates are significantly different at the 1 percent level. 
mobility by the tax and social protection systems was effective from the beginning. In each year and in both regions of Germany the values of the Bartholomew index for net equivalent income mobility are smaller than the values based on gross equivalent labor income (compare Figures 3 and 4). Moreover, the gaps between the values became smaller each year, and the value for the eastern states was finally very close to that in the western states for the transition from 1994 to 1995. As one can conclude from Table A1 in the Appendix, the difference in the Bartholomew index between the eastern and the western states was 0.26 for the transition 1990-91, or 39.5 percent of the West German index value for 199091. For the transition 1994-95, this difference has fallen to 0.05 or 7.6 percent of the West German index value for 1990-91. Compared to the level of income mobility in West Germany in 1990-91, the mobility difference at the end of the observation period is less than 20 percent of its initial value. It is also very small in absolute numbers.

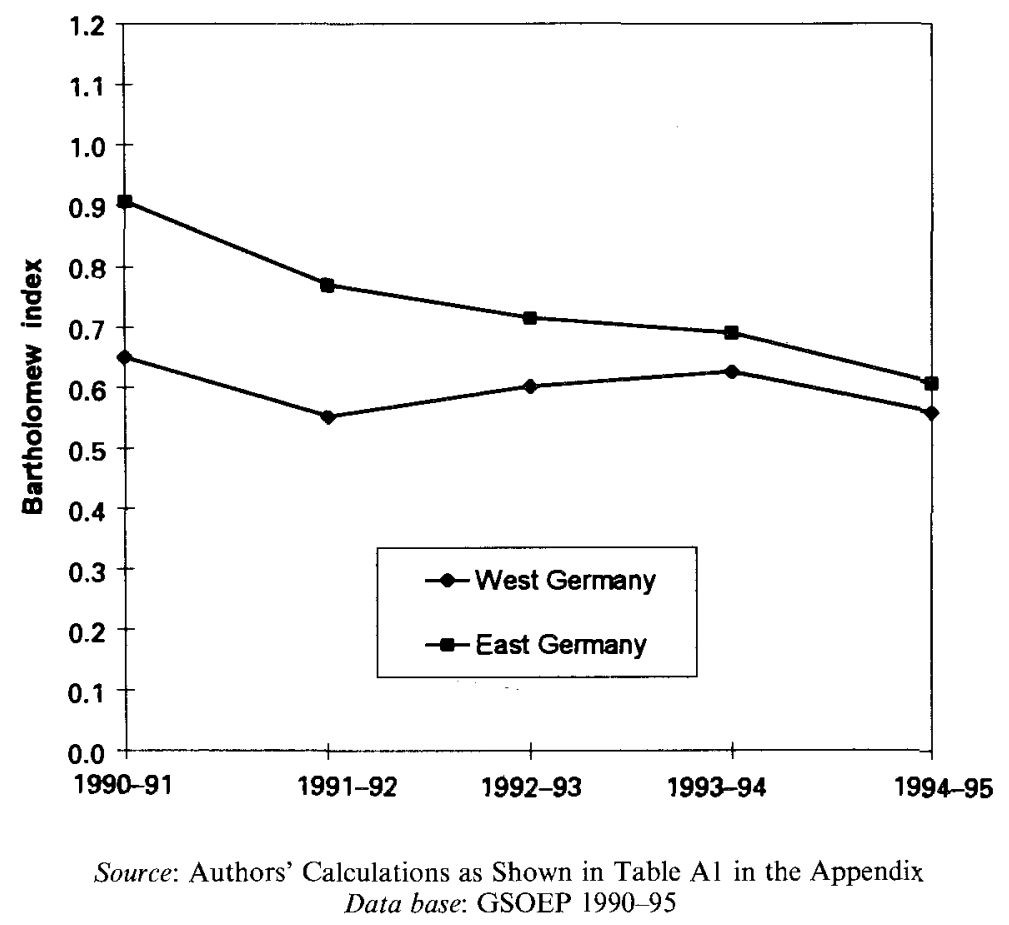

Figure 4. Net Equivalent Income Mobility in Regions of Germany

One can conclude from these results that the complete transfer of the West German tax system and social protection system to the eastern states immediately after reunification was quite successful in easing the added turmoil and economic risks that accompanied the transition from a centrally planned economy to a market economy. It should be noted, however, that the fact that both regions of Germany have approximately the same degree of mobility of net equivalent 
income in 1995 does not mean they have the same level of net equivalent income. Net equivalent income in the eastern states in 1995 was only 74 percent that of the western states in $1995 .^{31}$

Net equivalent income inequality was lower than gross equivalent labor income inequality in both parts of the country in 1990 as well as in 1995. This result is not very surprising given the extensive tax system and social protection systems in Germany. Net equivalent income inequality grew in both parts of Germany to an extent that is roughly comparable to that of the other income concepts. Also, inequality in the east is lower than in the west in both years, with the gap diminishing over time (see Table 3 ).

\section{Concluding Remarks}

This paper has shown that mobility of gross individual labor income, gross equivalent labor income and net equivalent income was much higher in East Germany than in West Germany during the first years after reunification, but has been greatly reduced until 1995. It has also shown that in both parts of the country the tax system and the social protection system serve to reduce income mobility.

Future work should compare income mobility with respect to the various income concepts internationally. Only after studying income mobility patterns in other market-oriented countries one can tell whether the levels observed in the western states of Germany during the transition period between 1990 and 1995 can be considered "normal" and, therefore, can legitimately serve as a point of reference for the study of economies in transition.

APPENDIX

TABLE A1

Bartholomow Index Values According to Different Income Concepts and in Different Regions of Germany

\begin{tabular}{|c|c|c|c|c|c|c|}
\hline \multirow[b]{2}{*}{ Transition } & \multicolumn{2}{|c|}{$\begin{array}{l}\text { Gross Individual } \\
\text { Labor Income }\end{array}$} & \multicolumn{2}{|c|}{$\begin{array}{l}\text { Gross Equivalent } \\
\text { Labor Income }\end{array}$} & \multicolumn{2}{|c|}{$\begin{array}{l}\text { Net Equivalent } \\
\text { Income }\end{array}$} \\
\hline & West & East & West & East & West & East \\
\hline $1990-91$ & 0.6291 & 0.996 & 0.7508 & 1.06 & 0.6495 & 0.9063 \\
\hline $1991-92$ & 0.5804 & 1.0669 & 0.6839 & 1.0492 & 0.5503 & 0.7685 \\
\hline $1992-93$ & 0.5992 & 0.9523 & 0.7159 & 0.9537 & 0.6002 & 0.7136 \\
\hline $1993-94$ & 0.5445 & 0.7764 & 0.6822 & 0.7945 & 0.6237 & 0.6882 \\
\hline $1994-95$ & 0.5189 & 0.7092 & 0.6610 & 0.7441 & 0.5564 & 0.6058 \\
\hline $1990-95$ & 0.8482 & 1.3995 & 1.1900 & 1.4083 & 1.0232 & 1.0380 \\
\hline
\end{tabular}

Source: Authors' calculations.

Data base: GSOEP 1990-95.

\section{REFERENCES}

Atkinson, A. B., L. Rainwater, and T. M. Smeeding, Income Distribution in OECD Countries, Evidence from the Luxembourg Income Study, OECD Social Policy Studies, No. 18, OECD, Paris, 1995.

${ }^{31}$ This value was calculated from the GSOEP data set used in this paper and refers to the subpopulation considered in this study. 
Bartholomew, D. J., Stochastic Models for Social Process, John Wiley and Sons, London, 1973.

Berntsen, R., Dynamik in der Einkommensverteilung privater Haushalte, Eine empirische Laengsschnittanalyse fuer die Bundesrepublik, Campus Verlag, Frankfurt/Main, 1992.

Buhmann, B. L., L. Rainwater, G. Schmauss, and T. M. Smeeding, Equivalence Scales, Well-Being, Inequality, and Poverty: Sensitivity Estimates across Ten Countries Using the Luxembourg Income Study Database, The Review of Income and Wealth, Series 34, 115-42, 1988.

Bundesministerium fuer Arbeit und Sozialordnung, Uebersicht ueber das Sozialrecht, Bonn, 1995. , Statistisches Taschenbuch 1996, Bonn, 1996.

Burkhauser, R. V., D. Holtz-Eakin, and S. E. Rhody, Labor Earnings Mobility and Inequality in the United States and Germany During the Growth Years of the 1980s, International Economic Review, 38, 775-94, 1997.

- Mobility and Inequality in the 1980s: A Cross-National Comparison of the United States and Germany, in S. Jenkins, A. Kapteyn, and B. v. Praag (eds.), The Distribution of Welfare and Household Production: International Perspectives, 111-78, Cambridge University Press, Cambridge, MA, 1998.

__ , T. M. Smeeding, and J. Merz, Relative Inequality and Poverty in Germany and the United States Using Alternative Equivalence Scales, The Review of Income and Wealth, Series 42, 381$400,1996$.

Duncan, G. J., R. D. Coe, E. Corcoran, M. S. Hill, S. D. Hoffman, and J. N. Morgan, Years of Poverty, Years of Plenty, The Changing Economic Fortunes of American Workers and Families, Institute for Social Research, University of Michigan, Ann Arbor, 1984.

Gustafsson, B., The Degree and Pattern of Income Immobility in Sweden, Review of Income and Wealth, Series 40, 67-86, 1994.

Habich, R. and P. Krause, Armut, in Statistisches Bundesamt (ed.), Datenreport 1994, Zahlen und Fakten ueber die Bundesrepublik Deutschland, Bundeszentrale fuer politische Bildung, 598-607, Bonn, 1994.

Hauser, R. and R. Berntsen, Einkommensarmut-Determinanten von Aufstiegen und Abstiegen, in R. Hujer, H. Schneider, and W. Zapf (eds.), Herausforderungen an den Wohlfahrtsstaat im strukturellen Wandel, 73-115, Campus Press, Frankfurt/Main 1992.

_- Die personelle Einkommensverteilung in den alten und neuen Bundeslaendern vor der Vereinigung-Probleme eines empirischen Vergleichs und der Abschaetzung von Entwicklungstendenzen, in G. Kleinhenz (ed.), Sozialpolitik im vereinten Deutschland II, 37-72, Duncker \& Humblot, Berlin, 1992.

_ and J. Faik, Strukturwandel der unteren Einkommensschichten in der Bundesrepublik Deutschland waehrend eines Vierteljahrhunderts. Gutachten im Auftrag des Bundesministeriums fuer Gesundheit, mimeo, Frankfurt/Main, 1996.

W. Glatzer, S. Hradil, G. Kleinhenz, T. Olk, and E. Pankoke, Ungleichheit und Sozialpolitik, Leske und Budrich, Opladen, 1996.

- and I. Becker, The Development of Income Distribution in the Federal Republic of Germany During the 1970s and 1980s, in P. Gottschalk, B. A. Gustafsson, and E. Palmer (eds.), Changing Patterns in the Distribution of Economic Welfare: An International Perspective, 184-219, Cambridge University Press, Cambridge, U.K., 1997.

- and G. Wagner, Die Einkommensverteilung in Ostdeutschland-Darstellung, Vergleich und Determinanten fuer die Jahre 1990 bis 1994, in R. Hauser (ed.), Sozialpolitik im vereinten Deutschland III, Schriften des Vereins fuer Socialpolitik Band 208/III, Duncker \& Humblot, Berlin, 1996.

Headey, B. and P. Krause, Rich and Poor: Stability or Change? West German Income Mobility 1984 93, Discussion Paper, No. 126, Deutsches Institut fuer Wirtschaftsforschung, Berlin, 1995.

Institut der deutschen Wirtschaft, Zahlen zür wirtschaftlichen Entwicklung der Bundesrepublik Deutschland, Deutscher Instituts-Verlag, Cologne, 1996.

Jarvis, S. and S. P. Jenkins, Changing Places: Income Mobility and Poverty Dynamics in Britain, Working Paper, No. 96-19, ESRC Research Centre on Micro-Social Change, University of Essex, Essex, 1996.

Lampert, H., Lehrbuch der Sozialpolitik, 3rd ed., Springer, Berlin, 1994.

Leibfried, S. and L. Leisering, Zeit der Armut, Lebenslaeufe im Sozialstaat, Suhrkamp, Frankfurt/ Main, 1995.

Mathwig, G. and R. Habich, Berufs- und Einkommensverlaeufe in Deutschland nach der Wiedervereinigung, in S. Hrardil and E. Pankoke (eds.), Aufstieg fuer alle?, KSPW Beitraege zum Bericht Ungleichheit und Sozialpolitik, Band 2.2, Leske \& Budrich, Opladen, 1996.

Mueller, K. and J. Frick, Die Einkommensmobilitaet (Nettoaequivalenzeinkommen) in den neuen und alten Bundeslaendern 1990-94, in S. Hrardil and E. Pankoke (eds.), Aufstieg fuer alle?, KSPW Beitraege zum Bericht Ungleichheit und Sozialpolitik, Band 2.2, Leske \& Budrich, Opladen, 1996. 
Pannenberg, M. and Rendtel, U., Dokumentation des Sozio-oekonomischen Paneis (SOEP): Erhebungsdesign, Fallzahlen und erhebungsbedingte Ausfaelle sowie die Schaetzung von Ausfallwahrscheinlichkeiten bis Welle 12 (1984 bis 1995), Discussion Paper, No. 173a, Deutsches Institut fuer Wirtschaftsforschung, Berlin, 1996.

Rendtel, U., Hochrechnung und Stichprobenfehler, in Deutsches Institut fuer Wirtschaftsforschung, Das Sozio-oekonomische Panel (SOEP), Benutzerhandbuch, Deutsches Institut fuer Wirtschaftsforschung, Berlin,1993.

Rohwer, G., Einkommensmobilitaet privater Haushalte 1984-89, in U. Rendtel and G. Wagner (eds.), Lebenslagen im Wandel-Zur Einkommensdynamik in Deutschland seit 1984, 437-56, Campus Press, Frankfurt/Main, 1991.

Sachverstaendigenrat zur Begutachtung der gesamtwirtschaftlichen Entwicklung, Jahresgutachten 1990-91, Bundestagsdrucksache, 1991. , Jahresgutachten 1995-96, Bundestagsdrucksache, 1995

Schlitgen, R., Einfuehrung in die Statistik, 6th ed., Oldenbourg Press, Munich, 1996.

Schlueter, C., Income Mobility in Germany: Evidence from Panel Data, Discussion Paper, No. 17, STICERD, London School of Economics, London, 1996.

Shorrocks, A. F., The Measurement of Mobility, Econometrica, Series 46, 1013-24, 1978a.

, Income Inequality and Income Mobility, Journal of Economic Theory, Series 19, 376-93, 1978b.

Steiner, V. and F. Kraus, Aufsteiger und Absteiger in der ostdeutschen Einkommensverteilung 198993, in M. Diewald and K. U. Mayer (eds.), Zwischenbilanz der Wiedervereinigung, Strukturwandel und Mobilitaet im Tranformationsprozeß, 189-212, Leske \& Budrich, Opladen, 1996.

Steiner, V. and P. A. Puhani, Die Entwicklung der Lohnstruktur im ostdeutschen Transformationsprozeß, Discussion Paper No. 96-03, Zentrum fuer Europaeische Wirtschaftsforschung, Mannheim, 1996.

Trede, M., Statistische Messung der Einkommensmobilitaet, Vandenhoeck \& Ruprecht, Goettingen, 1997.

Wagner, G. G., R. V. Burkhauser, and F. Behringer, The English Language Public Use File of the German Socio-Economic Panel, Journal of Human Resources, Series 28, 429-33, 1993. 